\title{
PHYSICAL ATTRIBUTES, TOTAL CARBON AND 13C NATURAL ABUNDANCE IN FERRALSOL UNDER DIFFERENT AGRICULTURAL SYSTEMS
}

\author{
Marcos Gervasio Pereira *1凹 ${ }^{*}$, Arcangelo Loss ${ }^{2}$, Roni Fernandes Guareschi 1 , \\ Fabiana da Costa Barros ${ }^{3}$, Marisa de Cássia Piccolo ${ }^{4}$, Adriano Perin 5 , Francirose \\ Shigaki 6, Otavio Augusto Queiroz dos Santos 1
}
${ }^{*}$ Federal Rural University of Rio de Janeiro. Agronomy Institute. Soils Department. Soil Genesis and Classification Laboratory, Seropédica, Rio de Janeiro, Brazil.
2 Santa Catarina Federal University. Agricultural Sciences Center, Engineering Rural Department, Florianópolis, Santa Catarina, Brazil.
${ }^{3}$ Federal Fluminense University. Pos-Graduate Program in Biosystems Engineering, Niterói, Rio de Janeiro, Brazil.
4 São Paulo University. Center for Nuclear Energy in Agriculture, Nutrient Cycle Laboratory, Piracicaba, São Paulo, Brazil
${ }^{5}$ Federal Goiano Institute. Plant Science Department, Rio Verde Campus, Rio Verde, Goiás, Brazil. ${ }^{6}$ Maranhão Federal University. Center for Agricultural and Environmental Sciences, Chapadinha, Maranhão, Brazil

DOI: https://doi.org/10.29121/granthaalayah.v8.i5.2020.205

Article Type: Research Article

Article Citation: Marcos Gervasio Pereira, Arcangelo Loss, Roni Fernandes Guareschi, Fabiana da Costa Barros, Marisa de Cássia Piccolo, Adriano Perin, Francirose Shigaki, and Otavio Augusto Queiroz dos Santos. (2020). PHYSICAL ATTRIBUTES, TOTAL CARBON AND 13C NATURAL ABUNDANCE IN FERRALSOL UNDER DIFFERENT AGRICULTURAL SYSTEMS. International Journal of Research -GRANTHAALAYAH, 8(5), 266$276 s$.

https://doi.org/10.29121/granthaalaya h.v8.i5.2020.205

Received Date: 14 May 2020

Accepted Date: 31 May 2020

Keywords:

Organic matter

No-Tillage System

Native Cerrado, Crop Succession or Rotation

\section{ABSTRACT}

The objective of this study was to evaluate the bulk density, total pore volume, carbon stock and natural abundance of 13C in Rhodic Ferralsol in no-tillage system (NTS) areas under different succession and rotation of cultures in the Cerrado of Goiás State, Brazil. In order to do so, NTS areas were selected in Montividiu, Goiás, under the same soil and climatic conditions as the following rotations: soybean-corn succession, soybeanmillet succession, soybean-corn-millet-beans-cotton rotation, soybeancorn-brachiaria succession and a pasture area (PA), used as a control. In each area, samples were collected at depths of $0.0-0.05,0.05-0.10,0.10-$ 0.20 , and $0.20-0.40 \mathrm{~m}$. The lowest levels of carbon content and stocks were verified in PA in comparison to the other areas evaluated. The NTS with soybean-corn-millet-beans-cotton crop rotation followed by NTS with soybean-corn-brachiaria succession were those that presented greater potential for carbon stock increase and total soil pore volume, as well as bulk density reduction. The origin of the soil organic matter in the NTS areas is related to plants employing the $\mathrm{C} 4$ photosynthetic cycle; however, for mixed C3 and C4 plant systems, the isotopic signature of $13 \mathrm{C}$ is reduced, mainly in areas with crop rotation. 
Marcos Gervasio Pereira, Arcangelo Loss, Roni Fernandes Guareschi, Fabiana da Costa Barros, Marisa de Cássia Piccolo, Adriano Perin, Francirose Shigaki, and Otavio Augusto Queiroz dos Santos

\section{INTRODUCTION}

The no-tillage system (NTS), with its three basic principles - maintenance of vegetal residues on the surface, crop rotation (CR), and minimum soil turning - was proposed for the Cerrado as an alternative to conventional methods to minimize the impacts on the soil owing to different forms of use (Carvalho et al., 2010; Loss et al., 2016).

However, in the Brazilian Cerrado region, one of the basic principles of NTS, has been replaced by crop succession (CS), mainly due to the limited number of economic crops for the autumn/winter season (Carneiro et al., 2013; Fidelis et al., 2003).

Some previous studies have indicated that NTS with second crop "safrinha" soybean-corn succession (SCS), in some situations, provides inadequate and insufficient soil coverage (Carneiro et al., 2013; Ceccon et al., 2013; Maria and Gomes, 2012), with lower soil organic matter (SOM) content and consequently, higher bulk density and resistance to penetration when compared to NTS with Cerrado region (Franchini et al., 2011).

However, the soybean-millet succession (SMS) under NTS has yielded dry mass (straw) yields above the minimum required amount (10 $\mathrm{Mg} \mathrm{ha}^{-1}$ ) for the adoption of NTS in the Brazilian Cerrado (Almeida et al., 2008; Brancalião and Moraes, 2008; Brancalião et al., 2007; Carneiro et al., 2008; Torres et al., 2008; Loss et al., 2012a,b), increasing the organic matter content in Ferralsols (Bressan et al., 2013; Pereira et al., 2010) and/or keeping the carbon (C) content similar to that found in the native Cerrado (Loss et al., 2012c).

Previous studies have shown that crop-livestock integration (CLI) allied to NTS tends to increase organic matter and carbon stocks in the soil, sometimes even to match and/or exceed the values found in areas of native vegetation of the Cerrado and NTS without grazing (Gazolla et al., 2013; Loss et al., 2012a,b,c; Souza et al., 2009). Among the reasons for this increase, we highlight the association of several factors that act together, such as: high dry mass production of the aerial part and roots of the brachiaria (Urochloa sp), input of bovine waste to the area; deposition of crop residue from annual crops and fertilizers used (Loss et al., 2012a,b,c; Souza et al., 2009).

There is a shortage of studies on the joint evaluation of areas with different types of NTS in the consolidation phase. More research is needed so that the efficiency of these management strategies in the long term can be verified, both in the carbon stock, as well as in the chemical and physical attributes of the soil.

Thus, the objective of this study was to evaluate the bulk density (Bd), total pore volume (TPV), carbon stock (Csto) and natural abundance of ${ }^{13} \mathrm{C}$ in a Rhodic Ferralsol in NTS areas under different succession and rotation of cultures in the Cerrado of Goiás State, Brazil.

\section{MATERIALS AND METHODS}

Samples of soil were collected from two rural properties in the municipality of Montividiu, Goiás $\left(17^{\circ} 27^{\prime} 5.2^{\prime \prime} S\right.$; $51^{\circ} 10^{\prime} 33.1^{\prime \prime} \mathrm{W}$; altitude $\left.890 \mathrm{~m}\right)$. According to the classification of Köppen, the climate in the region is tropical wetdry (Aw), with two defined seasons, the rainy season (October to April) and the dry season (May to September). The average temperature is $22^{\circ} \mathrm{C}$ and average annual rainfall is $1740 \mathrm{~mm}$. In the study area, the soils were classified as Rhodic Ferralsol according WRB (2014) and Latossolo Vermelho Distroférrico according Santos et al. (2013).

Four cultivation areas of consolidated NTS were selected: 1-NTS under soybean-corn succession (SCS), 2soybean-millet succession (SMS), 3-soybean-corn-millet-beans-cotton rotation (SCMBCR), and, 4- soybean-cornbrachiaria succession (SCBS). Samples were also collected in a pasture area (PA) adjacent to the growing areas.

The PA of Urochloa decumbens had been cultivated with an approximate stocking rate of 1.5 animal units per hectare. The SCS area $\left(17^{\circ} 08^{\prime} 59.8^{\prime \prime}\right.$ S; $51^{\circ} 11^{\prime} 23.4^{\prime \prime} \mathrm{W}$; altitude $\left.885 \mathrm{~m}\right)$ is located at Estreito Ponte de Pedra Farm, and was opened in 1981, with the removal of the native Cerrado, and for 16-years old it has been cultivated under NTS

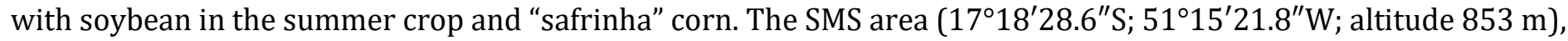
is also located at the same farm and has a history of 33-years old of cultivation, with NTS adopted in 1998 after a conventional system (plowing and harrowing of soil) of soybean planting in the summer. This area was cultivated with NTS soybean in the summer and "safrinha" corn up to 2004, and since then has been cultivated with SMS.

The SCBS and SCMBCR areas are in Vargem Grande Farm, belonging to the Agropecuária Peeters $\left(17^{\circ} 21^{\prime} 85.4^{\prime \prime}\right.$; $51^{\circ} 28^{\prime} 59.9^{\prime \prime} \mathrm{W}$; altitude $859 \mathrm{~m}$ ). The NTS area with SCBS was cultivated with soybean in the summer and "safrinha" 
corn interspersed with brachiaria for cattle. Finally, the SCMBCR area started to be used from 1975, with the removal of the native Cerrado and cultivation of pasture for 10 years. Subsequently, the conventional cultivation with soybean and corn was carried out for 10 years, and for 19 years it has been cultivated under NTS with SCMBCR. The sequence of this Brazilian Cerrado region showed small variations over the years, according to the financial viability for the adoption of each culture.

In view of the above, it is emphasized that all NTS areas evaluated are in the implantation phase considered as consolidation (10 to 20 years old).

The basic fertilization of the main crops of the agricultural systems was as follows: 1) SCS: a) soybean (summer)-165 kg ha-1 of potassium chloride applied before sowing $+186 \mathrm{~kg} \mathrm{ha}^{-1}$ of the formula (N-P-K) 09-43-00, applied in the sowing groove; b) "safrinha" corn-450 kg ha-1 of formula 07-28-14 at planting and $100 \mathrm{~kg} \mathrm{ha}^{-1}$ of urea, as coverage at 25 days after the emergency (DAE); 2) SMS: a) soybean (summer) - $165 \mathrm{~kg} \mathrm{ha}^{-1}$ of potassium chloride applied before sowing $+190 \mathrm{~kg} \mathrm{ha}^{-1}$ of the formula 09-43-00 applied to the sowing groove; b) milletcultivated without fertilization; 3) SCBS: a) soybean (summer) -475 kg ha-1 of formula 02-20-20; b) "safrinha" corn-450 kg ha-1 of formula 07-28-14 at planting and $100 \mathrm{~kg} \mathrm{ha}^{-1}$ of urea, as coverage at $25 \mathrm{DAE}$; c) brachiaria cultivated without fertilization; 4) SCMBCR: a) soybean (summer) $-550 \mathrm{~kg} \mathrm{ha}^{-1}$ of formula 02-20-18; b) "safrinha" corn-450 kg ha-1 of formula 07-28-14 at planting and $100 \mathrm{~kg} \mathrm{ha}^{-1}$ of urea, as coverage at $25 \mathrm{DAE}$; c) millet cultivated without fertilization; d) beans-400 kg ha-1 of formula 05-20-10 at planting and $90 \mathrm{~kg} \mathrm{ha}^{-1}$ of urea, as coverage at 25 DAE; e) cotton-500 kg ha-1 of formula 10-30-10 at planting and $250 \mathrm{~kg} \mathrm{ha}^{-1}$ of formula 20-00-20 as coverage.

The NTS areas with SCS, SMS, SCBS received liming in the years 2014, 2014, 2013, respectively, with surface application to the soil in the following amounts: 1300 to $2800 \mathrm{~kg} \mathrm{ha}^{-1}$ (application with varied rate), $2000 \mathrm{~kg} \mathrm{ha}^{-1}$, $4000 \mathrm{~kg} \mathrm{ha}^{-1}$.

In each area, a representative plot of 2.25 ha $(150 \times 150 \mathrm{~m})$ was demarcated, and five trenches of approximately $1 \times 1 \mathrm{~m}$ at the surface and a depth of $0.60 \mathrm{~m}$ were randomly positioned in each of them. Undisturbed and disturbed samples soil were collected of each area (treatment), with five replicates per treatment. As this is not an experimental design experiment, sampling was performed according to statistical procedures for experimental design with randomization constraints (Ferreira et al., 2012).

Afterwards, in each of the trenches, in the different areas, the undisturbed samples were collected, with the aid of a volumetric ring with $50 \mathrm{~cm}^{-3}$ (Donagemma et al., 2011), at depths of $0-0.05 ; 0.05-0.10 ; 0.10-0.20$ and $0.20-0.40$ $\mathrm{m}$, for determine the bulk density (Bd). Deformed samples were also collected in these areas, at depths of $0-0.05$; $0.05-0.10 ; 0.10-0.20$ and $0.20-0.40 \mathrm{~m}$, with the aid of an auger. These samples (each composed of 10 single samples) were collected along a zigzag line, with $3 / 4$ of the samples collected between the planting rows and $1 / 4$ in the rows. The soil samples were air-dried, crushed, and passed through a $2 \mathrm{~mm}$ mesh sieve to obtain the air-dried fine soil, which was then used for chemical characterization and granulometric analysis (Donagemma et al., 2011) (Table 1).

Bd was determined by the volumetric ring method (Donagemma et al., 2011). The density of particles (Pd) was determined by the volumetric balloon method, in order to use these data together with Bd to calculate the total porosity volume (TPV), which is calculated by the equation, according Donagemma et al. (2011):

$\operatorname{TPV}(\%)=(1-(\mathrm{Bd} / \mathrm{Pd})) \times 100$.

The $\mathrm{C}$ contents were quantified by dry combustion by CHNS analyzer (Elementar Analysensysteme GmbH, Hanau, Germany). Based on the $\mathrm{C}$ contents and $\mathrm{Bd}$, the Csto were calculated by the equivalent mass method (Sisti et al., 2004), as described below:

$$
C_{S}=\sum_{i=1}^{n-1} C_{T i}+\left[M_{T n}-\left(\sum_{i=1}^{n} M_{T i}-\sum_{i=1}^{n} M_{S i}\right)\right] C_{T n}
$$

Were:

$$
C_{S}=\text { total stock }\left(\mathrm{Mg} \mathrm{ha}^{-1}\right) ;
$$


$\sum_{i=1}^{n-1} C_{T i}=$ sum of carbon from the most superficial to the deepest layer of the soil profile evaluated in a specific experimental area $\left(\mathrm{Mg} \mathrm{ha}^{-1}\right)$;

$\sum_{i=1}^{n} M_{T i}$

= sum of soil mass from the most superficial to the deepest layer of the soil profile investigated in a specific experimental area $\left(\mathrm{Mg} \mathrm{ha}^{-1}\right)$;

$\sum_{i=1}^{n} M_{S}$

= sum of soil mass from the most superficial to the deepest layer of the soil profile sampled as a reference treatment $\left(\mathrm{Mg} \mathrm{ha}^{-1}\right)$;

$M_{T n}=$ soil mass in the deepest layer of the soil profile assessed in a specific experimental area $\left(\mathrm{Mg}^{-}\right.$ 1);

$C_{T n}=$ cqrbon level at the deepest layer of the soil profile studied in a specific experimental area (Mg C $\mathrm{Mg}^{-1}$ de solo).

The $\delta^{13} \mathrm{C}(\%)$ isotope analysis was done with the aid of the Finnigan Delta Plus mass spectrometer, at the Laboratory of Isotope Ecology (CENA-USP), Piracicaba, São Paulo. The results were expressed as delta ${ }^{13} \mathrm{C}(\% 0)$, in relation to the international standard PDB (Belemnitella Americana from the Pee Dee formation), were used to evaluate the contribution of the remaining carbon of the cerrado $\left(\mathrm{C}_{3}\right.$ plants) and that introduced by pasture (plants $\mathrm{C}_{4}$ ) in each of the areas.

The areas (land use systems) evaluated were under the same topographic and edaphoclimatic conditions (relief, soil class and texture, temperature, and precipitation), differing only in vegetation cover, and land use. Thus, the results were evaluated as a completely randomized design with five replicates for each area and depth. The data normality and homogeneity were analyzed through the Lilliefors and Bartlet tests, respectively. Subsequently, the results were submitted to analysis of variance by the F test, and significant means were compared using the $t$-test at $5 \%$ probability, using the Assistat statistical software.

Table 1: Chemical attributes and granulometric analysis of the study areas evaluated.

\begin{tabular}{|c|c|c|c|c|c|c|c|c|c|c|}
\hline & $\mathrm{pH}$ & $\mathrm{P}$ & $\mathrm{Ca}$ & $\mathrm{Mg}$ & $\mathrm{K}$ & $\mathrm{Al}$ & $\mathrm{H}+\mathrm{Al}$ & Clay & Silt & Sand \\
\hline Areas & $\mathrm{H}_{2} \mathrm{O}$ & $\mathrm{mg} \mathrm{kg}^{-1}$ & \multicolumn{5}{|c|}{$-\mathrm{cmol}_{\mathrm{c}} \mathrm{kg}^{-1}$} & \multicolumn{3}{|c|}{------ g kg-1-------- } \\
\hline & \multicolumn{10}{|c|}{$0.0-0.05 \mathrm{~m}$} \\
\hline PA & 5.7 & 2.1 & 3.9 & 4.7 & 0.2 & 0.0 & 7.3 & 600 & 190 & 210 \\
\hline SCS & 5.7 & 24 & 2.3 & 2.5 & 0.3 & 0.0 & 3.3 & 579 & 290 & 130 \\
\hline SMS & 6.2 & 16 & 3.8 & 1.8 & 0.1 & 0.0 & 2.3 & 449 & 368 & 182 \\
\hline SCBS & 5.9 & 27 & 4.3 & 2.3 & 0.2 & 0.0 & 2.7 & 532 & 245 & 222 \\
\hline \multirow[t]{2}{*}{ SCMBCR } & 5.6 & 25 & 3.6 & 2.4 & 0.2 & 0.0 & 4.0 & 450 & 345 & 203 \\
\hline & \multicolumn{10}{|c|}{$0.05-0.10 \mathrm{~m}$} \\
\hline PA & 5.6 & 1.5 & 3.0 & 3.0 & 0.1 & 0.0 & 5.0 & 570 & 240 & 190 \\
\hline SCS & 5.1 & 21 & 0.8 & 1.1 & 0.2 & 0.0 & 3.8 & 537 & 304 & 158 \\
\hline SMS & 5.5 & 35 & 1.1 & 1.3 & 0.1 & 0.0 & 5.7 & 476 & 385 & 138 \\
\hline SCBS & 5.8 & 21 & 4.3 & 1.5 & 0.2 & 0.0 & 3.3 & 579 & 226 & 193 \\
\hline \multirow[t]{2}{*}{ SCMBCR } & 5.3 & 13 & 2.4 & 1.4 & 0.1 & 0.0 & 4.0 & 478 & 376 & 145 \\
\hline & \multicolumn{10}{|c|}{$0.10-0.20 \mathrm{~m}$} \\
\hline
\end{tabular}


Physical Attributes, Total Carbon And 13c Natural Abundance in Ferralsol Under Different Agricultural Systems

\begin{tabular}{|l|c|c|c|c|c|c|c|c|c|c|}
\hline PA & 5.5 & 1.7 & 2.5 & 1.7 & 0.1 & 0.0 & 5.5 & 590 & 220 & 190 \\
\hline SCS & 5.2 & 5 & 0.6 & 0.4 & 0.2 & 0.0 & 4.5 & 590 & 295 & 114 \\
\hline SMS & 5.6 & 12 & 1.1 & 0.8 & 0.1 & 0.0 & 4.9 & 502 & 377 & 119 \\
\hline SCBS & 5.6 & 12 & 2.1 & 1.8 & 0.2 & 0.0 & 5.5 & 591 & 243 & 165 \\
\hline SCMBCR & 5.0 & 5 & 0.9 & 1.0 & 0.1 & 0.0 & 4.3 & 487 & 368 & 144 \\
\hline $0.20-0.40 \mathrm{~m}$ \\
\hline PA & 5.5 & 1.2 & 1.8 & 1.2 & 0.1 & 0.0 & 7.5 & 590 & 220 & 180 \\
\hline SCS & 5.1 & 2 & 0.3 & 0.6 & 0.1 & 0.1 & 3.6 & 591 & 311 & 97 \\
\hline SMS & 5.5 & 3 & 0.9 & 0.8 & 0.1 & 0.0 & 3.8 & 499 & 389 & 111 \\
\hline SCBS & 5.2 & 2 & 0.6 & 0.6 & 0.1 & 0.0 & 2.7 & 595 & 268 & 136 \\
\hline SCMBCR & 5.0 & 2 & 0.3 & 1.0 & 0.1 & 0.0 & 3.5 & 498 & 337 & 164 \\
\hline
\end{tabular}

$\mathrm{PA}=$ pasture area, $\mathrm{SCS}=$ soybean-corn succession, $\mathrm{SMS}=$ soybean-millet succession, $\mathrm{SCBS}=$ soybean-cornbrachiaria succession, SCMBCR = soybean-corn-millet-beans-cotton rotation.

\section{RESULTS AND DISCUSSIONS}

In the PA, the lowest levels of $C$ content $(0.0-0.40 \mathrm{~m})$ and Csto $(0.0-0.20 \mathrm{~m} ; 0.20-0.40 \mathrm{~m})$ were verified in comparison to the other areas evaluated (Figure 1 and Table 2). Such results occurred due to a set of factors, such as low productivity, absence of management (mainly maintenance fertilization) and intensive grazing. The history of the PA shows that it doesn't receive annual maintenance fertilization. Similar results were also reported by Guareschi et al. (2012), Gazolla et al. (2013), Siqueira Neto et al. (2010). These studies verified lowest levels of $\mathrm{C}$ content and Csto in areas of PA compared with native vegetation (Cerrado) and NTS. The authors reported that the lower values of $C$ and Csto in PA were due to the lower deposition of plant residues compared to the other areas.

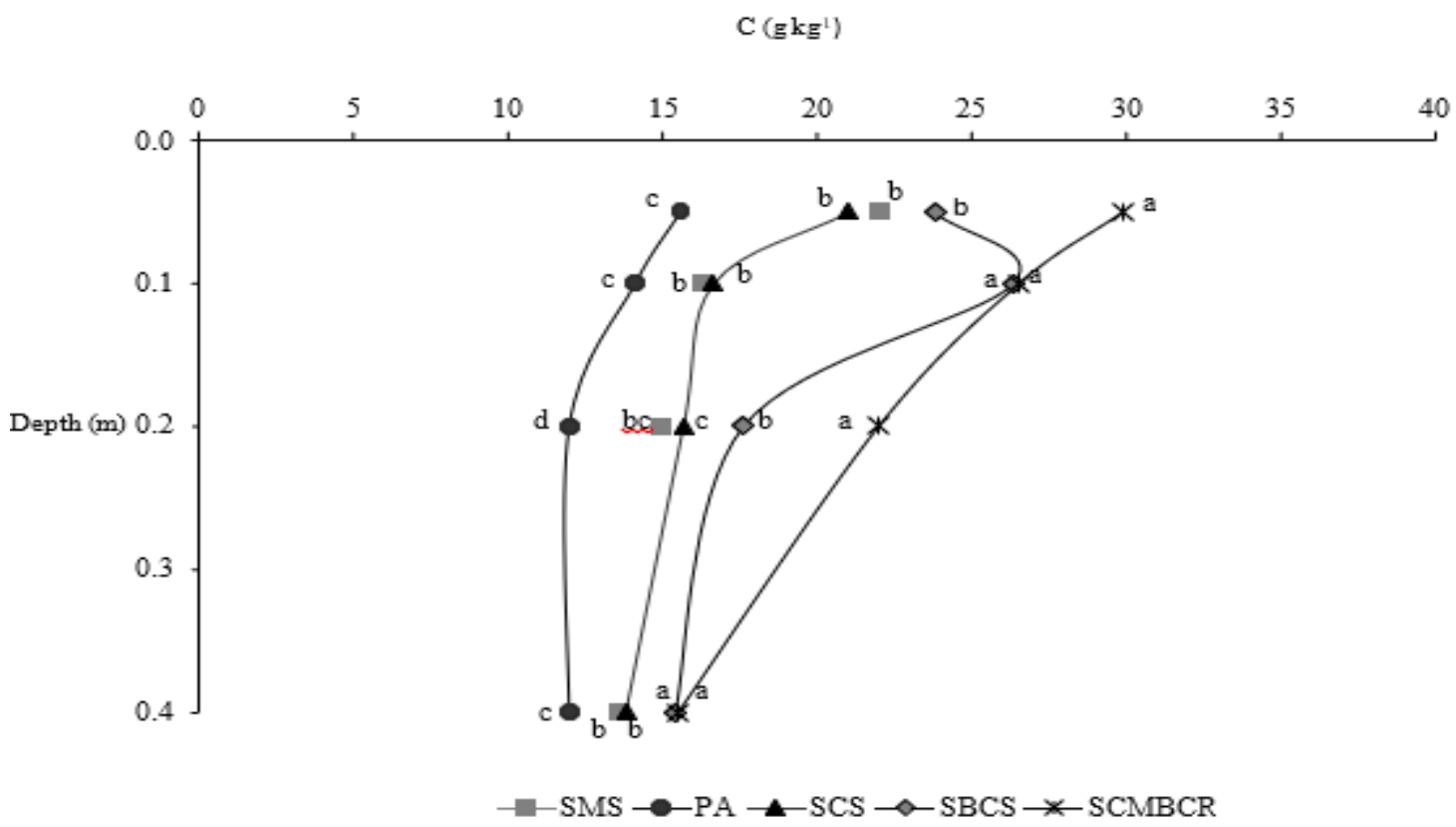

Figure 1: Total organic carbon (C) content of the soil in the evaluated areas, Goias State, Brazil.

Means followed by the same lowercase letter between areas, in each depth, do not differ by t-test $(\mathrm{p}<0.05) . \mathrm{PA}=$ pasture area, $\mathrm{SCS}=$ soybean-corn succession, $\mathrm{SMS}=$ soybean-millet succession, $\mathrm{SCBS}=$ soybean-corn-brachiaria succession, SCMBCR = soybean-corn-millet-beans-cotton rotation 
According Loss et al. (2019), the higher contribution of plant residues recorded in NTS than in the pasture area can be related to better soil fertility conditions in the NTS (Table 1), which favors plant growth and subsequent input and surface accumulation. These authors too reported that high production of plant litter in the Cerrado area is attributed to greater climatic stability under the tree canopy and the absence of anthropogenic intervention.

Table 2: Carbon stock (Csto) of the soil in the evaluated areas, Goias State, Brazil.

\begin{tabular}{|c|c|c|c|c|}
\hline Systems & \multicolumn{4}{|c|}{ Depth (m) } \\
\hline Evaluated & $0.0-0.05$ & $0.05-0.10$ & $0.10-0.20$ & $0.20-0.40$ \\
\hline \multicolumn{5}{|c|}{ Csto (Mg ha-1) } \\
\hline $\mathrm{PA}$ & $6.69 \mathrm{c}$ & $6.79 \mathrm{c}$ & $14.21 \mathrm{c}$ & $25.84 \mathrm{~b}$ \\
\hline SCS & $8.62 \mathrm{~b}$ & $11.19 \mathrm{~b}$ & $16.63 \mathrm{c}$ & $30.97 \mathrm{a}$ \\
\hline SMS & $9.05 \mathrm{~b}$ & $10.94 \mathrm{~b}$ & $16.73 \mathrm{c}$ & $30.97 \mathrm{a}$ \\
\hline SCBS & $10.04 \mathrm{~b}$ & $13.92 \mathrm{a}$ & $19.82 \mathrm{~b}$ & $34.79 \mathrm{a}$ \\
\hline SCMBCR & $12.46 \mathrm{a}$ & $13.71 \mathrm{a}$ & $24.33 \mathrm{a}$ & $35.58 \mathrm{a}$ \\
\hline
\end{tabular}

The SCMBCR showed higher levels of $\mathrm{C}$ and Csto $(0.0-0.05 \mathrm{~m} ; 0.10-0.20 \mathrm{~m})$ compared to the other cultivated areas (SCS, SMS, and SCBS) (Figure 1 and Table 2). According to Franchini, Costa and Debiasi et al. (2011) this pattern occurs because crop rotation allows an increase in the phytomass (aerial part and roots) additions to the soil which, together with the adoption of the NTS, results in an increase of SOM content. In addition to the differences in the amount of phytomass added to the soil, another factor that contributes to the increase in Csto is the fact that the different rotation cultures contribute organic materials of differing quality $(\mathrm{C} / \mathrm{N}$ ratio, lignin content and polyphenols, among others) to the soil in NTS, which consequently alters their rate of decomposition and the formation of humic and non-humic substances (Guareschi et al., 2018). Similar results are presented by Campos et al. (2011); Franchini et al. (2011); and Guareschi et al. (2018) who, when comparing areas of NTS with native Cerrado in relation to areas with conventional system, also verified higher levels of $\mathrm{C}$ and Csto in the areas of NTS with native Cerrado.

In general, the content of C (0.0-0.40 m) and Csto $(0.0-0.20 \mathrm{~m})$ was higher in the SCMBCR area than in the SCS and SMS areas (Figure 1 and Table 2). Similar patterns were observed for the SCBS area in relation to SCS and SMS areas with respect to $C$ content $(0.05-0.10,0.20-0.40 \mathrm{~m})$ and Csto $(0.05-0.20 \mathrm{~m})$ (Figure 1 and Table 2). This is thought to be owing to the larger number and variety of species cultivated in the SCMBCR and SCBS in relation to the successions evaluated. According to Campos et al. (2011) the entry of $C$ into soil increases with the diversification of the cultivation system. Thus, the inclusion of species with an aggressive root system and the long-term entry of different types of crop residues into soils managed under NTS associated with native Cerrado increase the reserves of C with greater lability (Bayer et al., 2006; Conceição et al., 2005; Guareschi et al., 2018) and increase the Csto of the soil.

It is also worth mentioning the superiority, in some cases, of C contents (0.05-0.20 $\mathrm{m}$ ) and Csto (0.05$0.40 \mathrm{~m}$ ) of SCMBCR and SCBS areas compared to PA (Figure 1 and Table 2). This pattern indicates that such soil management practices are promoting a positive impact on soil quality, recovering soil C levels to the original growing conditions.

Evaluated the total organic carbon (TOC) content in soil cultivated with onions in succession or rotation with other species (e.g., grasses, and, legumes) in NTS, Comin et al. (2018) reported that winter grasses in rotation with maize preceding onion crops in NTS increases TOC, and, higher TOC is found in areas with more soil cover plant species in rotation. The results found by Comin et al. (2018) indicated that the adopting soil management systems with conservationist bases that use permanent soil coverage and crop rotation can maintain or improve the SOM content, as well as observed in this study (Figure 1). 
The density of particles (Pd) did not present statistical difference between the areas and depths analyzed (Table 3). This result is due to the areas presenting the same soil class and mineralogical composition of sand and clay fraction, constituted mainly by quartz and kaolinite, respectively (Gazolla et al., 2013).

In the 0.0-0.05 m layer, the area with SCMBCR presented a lower Bd value and higher TPV in relation to the other areas evaluated (Table 3). It can be affirmed that this result is due to the higher levels of $\mathrm{C}$ contents of SCMBCR compared to the other cultivated areas. This pattern occurs because NTS areas with native Cerrado present a continuous supply of organic material by the vegetal residues and/or root exudates, whose subproducts are constituted by organic molecules in several phases of decomposition, acting as an agent of formation and stabilization of the aggregates, providing better soil structuring, which can promote reduction in Bd and increase TPV or TP (Franchini et al., 2011; Laurindo, 2009).

In the $0.05-0.10 \mathrm{~m}$ layer, the lowest values of Bd and highest TPV values of the areas SCMBCR and SCBS in relation to the PA (Table 3) stood out. As previously discussed, these results are related to the higher $\mathrm{C}$ content in these areas than that in PA, as well as being due to the low productivity of the grass associated with the animal trampling effect evident in the area, which possibly compacted the soil (Gazolla et al., 2013).

At other depths $(0.10-0.40 \mathrm{~m})$ the managed systems presented Bd and TPV similar to each other (Table 3). These areas present, up to $0.40 \mathrm{~m}$ depth, Bd below the "critical limit of 1.30 to 1.40 for clayey soil," which is harmful to the development of the roots (Reichert et al., 2003). Thus, it can be inferred that the Bd of the studied soils does not adversely affect the development of cultivated crops in the areas.

Table 3: Bulk density (Bd), particle density (Pd) and total pore volume (TPV) of the evaluated areas, Goias State, Brazil.

\begin{tabular}{|l|c|c|c|}
\hline \multirow{2}{*}{$\begin{array}{l}\text { Systems } \\
\text { Evaluated }\end{array}$} & Bd & Pd & TPV \\
\cline { 2 - 4 } $0.0-0.05$ & $1.20 \mathrm{a}$ & $2.08 \mathrm{a}$ & $42.01 \mathrm{c}$ \\
\hline PA & $1.16 \mathrm{a}$ & $2.19 \mathrm{a}$ & $49.24 \mathrm{~b}$ \\
\hline SCS & $1.16 \mathrm{a}$ & $2.18 \mathrm{a}$ & $46.59 \mathrm{~b}$ \\
\hline SMS & $1.14 \mathrm{a}$ & $2.15 \mathrm{a}$ & $46.82 \mathrm{~b}$ \\
\hline SCBS & $0.99 \mathrm{~b}$ & $2.15 \mathrm{a}$ & $53.96 \mathrm{a}$ \\
\hline SCMBCR & \multicolumn{3}{|c|}{} \\
\hline $0.05-0.10$ & $1.21 \mathrm{a}$ & $2.16 \mathrm{a}$ & $43.70 \mathrm{~b}$ \\
\hline PA & $1.17 \mathrm{abc}$ & $2.16 \mathrm{a}$ & $48.20 \mathrm{a}$ \\
\hline SCS & $1.18 \mathrm{ab}$ & $2.17 \mathrm{a}$ & $45.36 \mathrm{a}$ \\
\hline SMS & $1.10 \mathrm{c}$ & $2.10 \mathrm{a}$ & $47.41 \mathrm{a}$ \\
\hline SCBS & $1.13 \mathrm{bc}$ & $2.21 \mathrm{a}$ & $48.94 \mathrm{a}$ \\
\hline SCMBCR & \multicolumn{3}{|c|}{} \\
\hline $0.10-0.20$ & $1.23 \mathrm{a}$ & $2.12 \mathrm{a}$ & $41.50 \mathrm{a}$ \\
\hline PA & $1.22 \mathrm{a}$ & $2.28 \mathrm{a}$ & $46.41 \mathrm{a}$ \\
\hline SCS & $1.26 \mathrm{a}$ & $2.21 \mathrm{a}$ & $42.99 \mathrm{a}$ \\
\hline SMS & $1.23 \mathrm{a}$ & $2.13 \mathrm{a}$ & $44.08 \mathrm{a}$ \\
\hline SCBS & $1.19 \mathrm{a}$ & $2.20 \mathrm{a}$ & $44.33 \mathrm{a}$ \\
\hline SCMBCR & $1.24 \mathrm{a}$ & $2.26 \mathrm{a}$ & $45.12 \mathrm{a}$ \\
\hline $0.20-0.40$ & $1.25 \mathrm{a}$ & $2.29 \mathrm{a}$ & $45.62 \mathrm{a}$ \\
\hline PA & $1.23 \mathrm{a}$ & $2.22 \mathrm{a}$ & $44.78 \mathrm{a}$ \\
\hline SCS & $1.28 \mathrm{a}$ & $2.21 \mathrm{a}$ & $42.28 \mathrm{a}$ \\
\hline SMS & \multicolumn{5}{|c|}{} \\
\hline SCBS & \multicolumn{5}{|c|}{} \\
\hline
\end{tabular}




\begin{tabular}{|l|c|c|c|}
\hline SCMBCR & $1.27 \mathrm{a}$ & $2.26 \mathrm{a}$ & $43.86 \mathrm{a}$ \\
\hline *Means followed by the same letter in the columns and in each depth do not \\
differ significantly between the systems evaluated, by the $t$-test at $5 \%$ probability.
\end{tabular}

The results of natural abundance of ${ }^{13} \mathrm{C}(\%)$ in the soil profile showed that the PA presented greater contribution of plant residues from $\mathrm{C}_{4}$ plants in all depths examined (Figure 2). This result is consistent, considering that this area has received input of plant residues from grazing for many years. Based on the literature, $\mathrm{C}_{3}$ plants have ${ }^{13} \mathrm{C}$ values between -33 and $-22 \%$, while in $\mathrm{C}_{4}$ plants such values are between 16 and $9 \%$ (Guareschi et al., 2014).

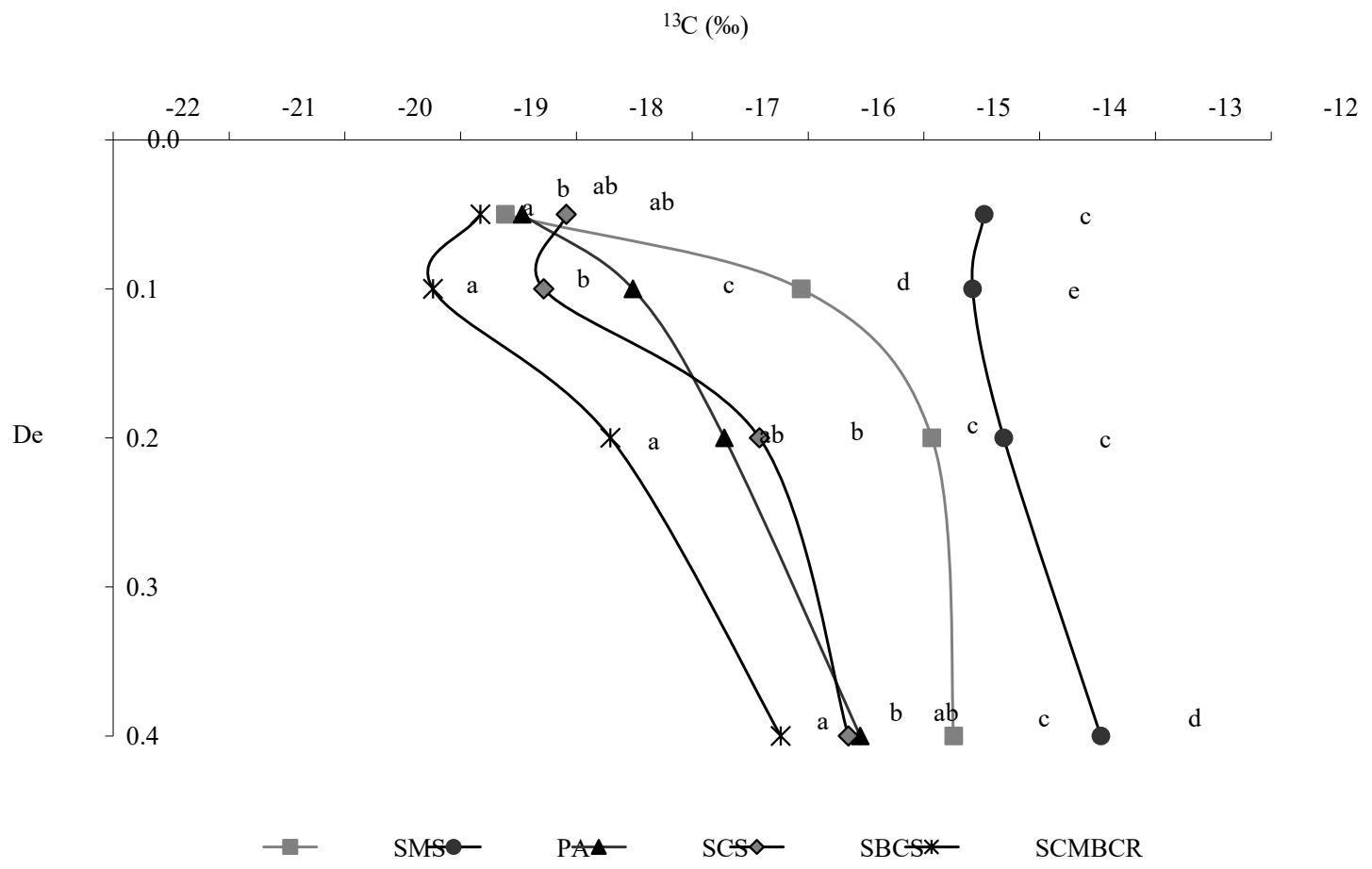

Figure 2: Natural abundance of $\delta^{13} \mathrm{C}$ in the soil profile of the evaluated areas, Goias State, Brazil.

Means followed by the same lowercase letter between areas, in each depth, do not differ by t-test $(\mathrm{p}<0.05)$. PA = pasture area, $\mathrm{SCS}=$ soybean-corn succession, $\mathrm{SMS}=$ soybean-millet succession, $\mathrm{SCBS}=$ soybean-corn-brachiaria succession, SCMBCR = soybean-corn-millet-beans-cotton rotation.

Among NTS areas, it is observed that, up to $0.40 \mathrm{~m}$ from the soil surface, the ${ }^{13} \mathrm{C}(\%)$ signal decreases as compared to that in the PA-that is, the signal approaches the average values established for $\mathrm{C}_{3}$ plants (between -33 and $-22 \%$ ), especially in the area with SCMBCR (Figure 2). This transitory effect may be occurring because, in these areas, organic matter has a greater contribution of vegetal residues derived mainly from $\mathrm{C}_{3}$ plants, such as soybean, beans, and cotton in SCMBCR area and soybean in the other NTS areas evaluated (Guareschi et al., 2014).

In the NTS without native Cerrado (SCS, SMS and SCBS), the isotopic signature of the $\mathrm{C}_{3}$ and $\mathrm{C}_{4}$ vegetation mixture was closer to the $\mathrm{C}_{4}(\mathrm{PA})$ vegetation signal (Figure 2). This is due to the lower supply of $\mathrm{C}_{3}$ plants in these systems when compared to SCMBCR, as well as the greater contribution of grasses (corn, millet and brachiaria) to the maintenance of these values. Siqueira Neto et al. (2010), when 
evaluating a chronosequence of NTS areas in the Cerrado, also showed that the isotopic signature was closer to the $\mathrm{C}_{4}$ vegetation signal, presumably due to greater contribution of cereal crop residues.

Studies carried out with the ${ }^{13} \mathrm{C}$ technique in the native Cerrado region in Goias, indicate that the isotopic variation found in the 0.0 to $0.40 \mathrm{~m}$ depth was predominantly from $\mathrm{C}_{3}$ plants, with values ranging from - 27 to - $24 \%$ (Loss et al., 2012a, 2019; Guareschi et al., 2014). Therefore, in areas in NTS, which have been native Cerrado in the past, the isotopic sign found indicates a significant contribution of $\mathrm{C}$ derived from $\mathrm{C}_{4}$ plants, such as corn (SCS), millet (SMS), corn + brachiaria (SCBS) and corn + millet (SCMBCR). Thus, part of the carbon content and stocks found (Figure 1 and Table 2) are derived from the current vegetation.

\section{CONCLUSIONS}

The no-tillage system with soybean-corn-millet-beans-cotton crop rotation followed by no-tillage system with soybean-corn-brachiaria succession were those that presented greater potential for carbon stock increase and total soil pore volume, as well as bulk density reduction.

The origin of the soil organic matter in the no-tillage system areas is related to plants employing the C4 photosynthetic cycle; however, for mixed C3 and C4 plant systems, the isotopic signature of $13 \mathrm{C}$ is reduced, mainly in areas with crop rotation.

\section{SOURCES OF FUNDING}

None.

\section{CONFLICT OF INTEREST}

None.

\section{ACKNOWLEDGMENT}

To Conselho Nacional de Desenvolvimento Científico e Tecnológico (CNPq). This study was financed in part by the Coordenação de Aperfeiçoamento de Pessoal de Nível Superior - Brasil (CAPES) - Finance Code 001.

\section{REFERENCES}

[1] Almeida, V. P.; Alves, M. C.; Silva, E. C.; oliveira, s. A. Rotação de culturas e propriedades físicas e químicas em Latossolo Vermelho de cerrado sob preparo convencional e semeadura direta em adoção. Revista Brasileira de Ciência do Solo, Viçosa, v.32, n.3, p.1227-1237, 2008.

[2] Bayer, C.; Martin-Neto, L.; Mielniczuk, J.; Pavinato, A.; Dieckow, J. Carbon sequestration in two Brazilian Cerrado soils under no-till. Soil Tillage Reschearch, Amsterdam, v.86, n.02, p.237-245, 2006.

[3] Brancalião, S. R.; Moraes, M. H. Alterações de alguns atributos físicos e das frações húmicas de um Nitossolo Vermelho na sucessão milheto-soja em sistema plantio direto. Revista Brasileira de Ciência do Solo, Viçosa, v.32, n.01, p. 393-404, 2008.

[4] Brancalião, S. R.; Moraes, M. H.; Lemos, L. B. Alterações de propriedades físicas de um Nitossolo Vermelho pela sucessão milheto-soja na fase de implantação do sistema de semeadura direta. Irriga, Botucatu, v.12, n.3, p.409-421, 2007.

[5] Bressan, S. B.; Nóbrega, J. C. A.; Nóbrega, R. S. A.; Barbosa, R. S.; Sousa, L. Plantas de cobertura e qualidade química de Latossolo Amarelo sob plantio direto no cerrado maranhense. Revista Brasileira de Engenharia Agrícola e Ambiental, Campina Grande, v.17, n.04, p. 371-378, 2013. 
Marcos Gervasio Pereira, Arcangelo Loss, Roni Fernandes Guareschi, Fabiana da Costa Barros, Marisa de Cássia Piccolo, Adriano Perin, Francirose Shigaki, and Otavio Augusto Queiroz dos Santos

[6] Campos, B. C.; Amado, T. J. C.; Bayer, C.; Nicoloso, R. S.; Fiorin, J. E. Carbon stock and its compartments in a subtropical Oxisol under long-term tillage and crop rotation systems. Revista Brasileira de Ciência do Solo, Viçosa, v.35, n.03, p.805-817, 2011.

[7] Carneiro, M. A. C.; Cordeiro, M. A. S.; Assis, P. C. R.; Moraes, E. S.; Pereira, H. S.; Paulino, H. B.; Souza, E. D. Produção de fitomassa de diferentes espécies de cobertura e suas alterações na atividade microbiana de solo de cerrado. Bragantia, Campinas, v. 67, n.02, p. 455-462, 2008.

[8] Carneiro, M. A.C.; Souza, E. D.; Paulino, H. B.; Sales, L. E. O.; Vilela, L. A. F.Atributos indicadores de qualidade em solos de cerrado no entorno do Parque Nacional das Emas, Goiás. Bioscience Journal, Uberlândia, v.29, n.06, p.1857-1868, 2013.

[9] Carvalho, J. L. N.; Avanzi, J. C.; Silva, M. L. N.; Mello, C. R. M.; Cerri, C. E.P. Potencial de sequestro de carbono em diferentes biomas do Brasil. Revista Brasileira de Ciência do Solo, Viçosa, v.34, n.2, p.277-289, 2010.

[10] Ceccon, G.; Staut, L. A.; Sagrilo, E.; Machado, L. A. Z.; Nunes, D. P.; Alves, V. B. Legumes and forage species sole or intercropped with corn in soybean-corn succession in midwestern Brazil. Revista Brasileira de Ciência do Solo, Viçosa, v.37, n.1, p.204-212, 2013.

[11] Conceição, P. C.; Amado, T. J. C.; Mielniczuk, J.; Spagnollo, E. Qualidade do solo em sistemas de manejo avaliada pela dinâmica da matéria orgânica e atributos relacionados. Revista Brasileira de Ciência do Solo, Viçosa, v.29, n.5, p.777-788, 2005.

[12] Comin, J. J.; Ferreira, L. B.; Santos, L. H.; Koucher, L. P.; Machado, L. N.; Santos Junior, E.; Mafra, A. L.; Kurtz, C.; Souza, M.; Brunetto, G.; Loss, A. Carbon and nitrogen contents and aggregation index of soil cultivated with onion for seven years using crop successions and rotations. Soil \& Tillage Research, v. 184, p. 195-202, 2018.

[13] Donagemma, G. K.; Campos, D. V. B. de; Calderano, S. B.; Teixeira, W. G.; Viana, J. H. M. Manual de Métodos de Análise de Solos. 2.ed. Rio de Janeiro: Embrapa Solos, 2011. 230 p.

[14] Ferreira, D.F.; Cargnelutti Filho, A.; Lúcio, A.D. Procedimentos estatísticos em planejamentos experimentais com restrições na casualização. Boletim Informativo da Sociedade Brasileira de Ciência do Solo, 37:37:1-35. 2012.

[15] Fidelis, R. R.; Rocha, R. N. C.; Leite, U. T.; Tancredi, F. D. Alguns aspectos para do plantio direto para a cultura da soja. Bioscience Journal, Uberlândia, v.19, n.1, p. 23-31, 2003.

[16] Franchini, J. C.; Costa, J. M.; Debiasi, H. Rotação de culturas: prática que confere maior sustentabilidade à produção agrícola no Paraná. Informações Agronômicas, Piracicaba, v.134, n.1, p.1-13, 2011.

[17] Gazolla, P. R.; Guareschi, R. F.; Perin, A. Estoque de carbono e atributos físicos de um Latossolo Vermelho em diferentes sistemas de manejo. Revista Brasileira de Ciências Agrárias, Recife, v.8, n.02, p.229-235, 2013.

[18] Guareschi, R. F.; Pereira, M. G.; Perin, A. Deposição de resíduos vegetais, matéria orgânica leve, estoques de carbono e nitrogênio e fósforo remanescente sob diferentes sistemas de manejo no cerrado goiano. Revista Brasileira de Ciência do Solo, Viçosa, v.36, n.3, p. 909-920, 2012.

[19] Guareschi, R. F.; Pereira, M. G.; Perin, A. Carbono, nitrogênio e abundância natural de 13C e 15N em uma cronossequência de agricultura sob plantio direto no cerrado goiano. Revista Brasileira de Ciência do Solo, Viçosa, v.38, n.4, p.1135-1142, 2014.

[20] Guareschi, R. F; Pereira, M. G.; Soares, P. F. C.; Barros, F. C.; Perin, A.; Rossi, C.Q. Compartimentos da matéria orgânica de um Latossolo sob diferentes tipos de semeadura direta. Semina: Ciências Agrárias, Londrina, v.39, n.2, p. 533-548, 2018.

[21] Laurindo, M. C. O. Atributos físicos do solo e teor de carbono orgânico em sistemas de plantio direto e cultivo mínimo. Engenharia na agricultura, Viçosa, v.17, n.5, p.367-374, 2009.

[22] Loss, A.; Pereira, M. G.; Perin, A.; Beutler, S. J.; Anjos, L. H.C. A. Carbon, nitrogen and natural abundance of 13C e $15 \mathrm{~N}$ of light-fraction organic matter under no-tillage system and crop-livestock integration in the Cerrado. Acta Scientiarum Agronomy, Maringá, v.34, n.4, p.468-474, 2012a.

[23] Loss, A.; Pereira, M. G.; Perin, A.; Coutinho, F. S.; Anjos, L. H C. Particulate organic matter in soil under different management systems in the Brazilian Cerrado. Soil Research, v. 50, p. 685-693, 2012b.

[24] Loss, A.; Pereira, M. G.; Perin, A.; Anjos, L. H.C. Carbon and nitrogen content and stock in no-tillage and croplivestock integration systems in the Cerrado of Goias State, Brazil. Journal of Agricultural Science, v. 4, p. 96105, 2012c.

[25] Loss, A; Pereira, M.G.; Torres, J.L.R. Carbono orgânico no solo sob sistemas conservacionistas no cerrado. In: Amaral Sobrinho, N. M.B.; Chagas, C. I.; Zonta, E. (Org.). Impactos Ambientais Provenientes da Produção 
Physical Attributes, Total Carbon And 13c Natural Abundance in Ferralsol Under Different Agricultural Systems

Agrícola: Experiências Argentinas e Brasileiras. 1aed.São Paulo: Rio de Janeiro: Livre Expressão, 2016, v. 1, p. 259-282.

[26] Loss, A.; Pereira, M.G.; Beutler, S. J.; Perin, A.; Piccolo, M.C.; Assunção, S.A.; Zonta, E. The impact of agricultural systems in the soil organic matter content in brazilian Cerrado. International Journal of Research Granthaalayah, 7(8), 220-244, 2019.

[27] Maria, I. C.; Gomes, L. J. P. Sobressemeadura de Braquiária em Soja para Produção de Palha em Sistema Plantio Direto na Região do Médio Paranapanema, SP. Boletim Científico, Campinas, v.17, n.1, p. 1-20, 2012.

[28] Pereira, M. G.; Loss, A.; Beutler, S. J.; Torres, J. L. R. Carbono, matéria orgânica leve e fósforo remanescente em diferentes sistemas de manejo do solo. Pesquisa Agropecuária Brasileira, Brasília, v.45, n.5, p.508-514, 2010.

[29] Reichert, J. M.; Reinert, D. J.; Braida, J. A. Qualidade dos solos e sustentabilidade de sistemas agrícolas. Ciência \& Ambiente, Santa Maria, v. 14, n.27, p.29-48, 2003.

[30] Santos, R.D.; Lemos, R.C.; Santos, H.G.; Ker, J.C.; Anjos, L.H.C. Manual de Descrição e Coleta de Solo no Campo. 5.ed. Viçosa: Sociedade Brasileira de Ciência do Solo, Embrapa Solos, 2005. 100p.

[31] Siqueira Neto, M.; Scopel, E.; Corbeels, M.; Cardoso, A. N.; Douzet, J. M.; Feller, C.; Piccolo, M. C.; Cerri, C. C.; Bernoux, M. Estoques de carbono do solo sob plantio direto em sistemas de cultivo no Cerrado do Brasil: Uma avaliação sincrônica na exploração. Soil \& Tillage Research, Amsterdam, v.110, n.1, p.187-195, 2010.

[32] Sisti, C. P. J.; Santos, H. P.; Kohhann, R.; Alves, B. J. R.; Urquiaga, S.; Boddey, R. M. Change in carbon and nitrogen stocks in soil under 13 years of conventional or zero tillage in southern Brazil. Soil Tillage Research, 76, 3958., 2004.

[33] Souza, E. D.; Costa, S. E. V. G. A.; Anghinoni, I.; Carvalho, P. C. F.; Andrigueti, M.; Cao, E. Estoque de carbono orgânico e de nitrogênio no solo em sistema de integração lavoura-pecuária em plantio direto, submetido a intensidades de pastejo. Revista Brasileira de Ciência do Solo, Viçosa, v.33, n.6, p.1829-1836, 2009.

[34] Torres, J. L. R.; Pereira, M. G.; Fabian, A. J. Produção de fitomassa por plantas de cobertura e mineralização de seus resíduos em plantio direto. Pesquisa Agropecuária Brasileira, Brasília, v.43, n.3, p.421-428, 2008.

[35] World Reference Base for Soil Resources - WRB: A framework for international classification, correlation and communication. Food and Agriculture Organization of the United Nations. Rome: IUSS/ISRIC/FA0; 2014. (World soil resources reports, 106). 